\title{
The Importance of Business Partnership on the World Wide Web
}

http://doi.org/10.21272/bel.4(1).68-79.2020

\section{Lívia Benita Kiss}

MSc, Department engineer, Georgikon Faculty, Pannon University, Keszthely, Hungary

\begin{abstract}
An integral component of successful entrepreneurial activity is the establishment of strong relations with partners, the form and type of which varies depending on the sphere of activity and its scope. Considering that a prerequisite for a business partnership is constant communication, the style, and quality of which mainly determines the success of doing business, the development of business communication skills becomes an object of continuous research by both scientists and enterprise managers. The main goal of this study was to examine the role and the importance of business partnerships in Google Trends. Another goal of the study was to look at how often the term business partnership appears in Google books, with the help of Google Books Ngram Viewer, as well as in a database of Science Direct, with the help of Science Direct's search function. The top year of the interest frequency of business partnership was 2004 in the Google Trends worldwide in business and industry categories. The bottom year of interest frequency was 2006. The geographic analysis revealed that most people searched in Botswana, in Jamaica, in Zimbabwe, in Ghana, and Uganda for the term business partnership. Interestingly, these countries are all located on the African continent, except Jamaica. Most people searched in Accra, in Nairobi, in Manila, in Quezon City, and Cebu for the term business partnership. The results of the bibliometric analysis of the relationship of business partnerships with other categories made it possible to conclude that people (mostly from the Philippines, Ethiopia, the USA, Canada, and Kenya) inquired about the joint venture and limited partnership. The conducted study revealed that from 1950 to 1970, the frequency of appearance of business partnership in the Google Books` database has been decreasing continuously. From 1972 the frequency has been growing gradually, then from 2006, the frequency has been decreasing gradually. The use of the term "business partnership" shows in the Science Direct a second-degree polynomial growing trend. Summarizing all these results, we can conclude that while people in developing countries in Africa and Jamaica were most sought for expressing business partnerships, people in developed countries were more interested in types of business partnerships.
\end{abstract}

Keywords: Business partnership, Google Trends, Google Books Ngram Viewer, Science Direct, Time Series Analysis.

JEL Classifications: C22, C88, P13.

This work is licensed under a Creative Commons Attribution 4.0 International License

Cite as: Kiss, L.B. (2020). The Importance of Business Partnership on the World Wide Web. Business Ethics and Leadership, 4(1), 68-79. http://doi.org/10.21272/bel.4(1).68-79.2020.

(C) The Author, 2020. This article is published with open access at Sumy State University.

\section{Introduction}

The partnership is a relationship in which two or more people, organizations or countries work together as partners. This is a formal agreement between parties to achieve a well-defined goal. There are many forms or types of partnership, one of which is a business partnership.

The partnership is crucial to the growth of any business venture. Merchants and traders from time immemorial have made use of the principle of a strategic partnership to conduct their businesses; the trend is still very much applicable today. A partnership manifests itself in different forms, ranging from business owners cooperating to invest in a project to share technical knowledge and ideas between firms. Whatever any business does, it is important to look for the right partnership agreement that benefits both parties.

According to Drucker (1996), the greatest change in corporate culture and the way business is being conducted may be the accelerated growth of relationships based on partnership.

The main goal of this study is to examine the role and the importance of business partnership in Google Trends from 2004 to the present worldwide by country in the fields of science, business. The search and query time 
was 14.01.2020. Another goal of the study is to look at how often the term business partnership appears in Google books, with the help of Google Books Ngram Viewer, over a period of time between 1950 and 2008, as well as in database of Science Direct, with the help of Science Direct's search function, over a period of time between 1950 and 2019.

\section{Literature Review}

Over the past two decades lot of researchers researched in foreign academic literature the partnership such as Barlow and Jashapara (1998), E. Bagdonas and Kazlauskienė (2000), Draft (2000), Harnesk (2004), Nakrošis (2007) and many others.

Partnerships exist when a business has multiple owners. Partnerships are often used when two or more owners want to participate in the day-to-day running of a business. The partnership begins when you start your business with another person, with or without paperwork. Partners can be individuals, companies, trusts, other partnerships or a combination of these examples. Although not required by law, most partners develop a written partnership agreement to outline how they will manage the business. Partners share in profits, losses and liabilities. The agreement shall also specify how profits and losses are to be distributed. If no written agreement is reached, the partnership is governed by the law of its state. The conclusion of the agreement will allow the partners to clearly define their expectations. One of the biggest disadvantages is that the owners have unlimited liability for all of the company's legal debts and liabilities. Liability caused by one partner is vulnerable to both parties.

\section{Definitions of business partnership}

When searching the Internet for the concept of a business partnership, we find the following definitions. The business partnership is a legal form of business operation between two or more individuals who share management and profits. The governments recognize several types of partnerships. The two most common are the general partnership and the limited partnerships (https://www.entrepreneur.com/encyclopedia/partnership).

The business partnership is a formal arrangement between two or more parties to manage and operate a business and share its profits. There are several types of partnership arrangements. In particular, in a partnership business, all partners share liabilities and profits equally, while in others, partners have limited liability. There also is the so-called silent partner, in which one party is not involved in the day-to-day operations of the business (https://www.investopedia.com/terms/p/partnership.asp).

When we search the scientific community for the concept of a business partnership, we find the following definitions.

The partnership is the relation between persons. They have agreed to share the profits of the business carried on by all or any of them acting for all (Indian Partnership Act, 1932).

The partnership is a relation. This relation subsists between persons carrying on business in common with a view of profit (Laws of Malaysia Act of Partnership Act, 1961).

The partnership is an association of two or more persons who engaged in business. This association the profits and losses are shared proportionally (Revised Uniform Partnership Act, 1994).

The common keywords of all three definitions are common business and profit-sharing. The Indian and Malaysian Acts define partnership as a person-to-person relation. According to the Revised Uniform Partnership Act, the partnership is an association of two or more persons. The partnership is, therefore, a person-to-person relation, an association of two or more persons who carries out joint business activities and distributes profits between them.

\section{Types of business partnership}

A business partnership is a legal relationship formed between two or more business partners. This relationship defines how they work to collect their business. There are different types of business partnerships. Each business partnership should include details about how potential legal issues are handled. The business agreement should include how much of the profit owners are entitled to, who's responsible for business debts and how the business is taxed. The different business partnership types have different advantages and disadvantages to consider (FinancePal by CommunityTax, 2019). 
Figure 1 shows the most known types of business partnership. There are general partnership, limited partnership, limited liability partnership and joint venture.

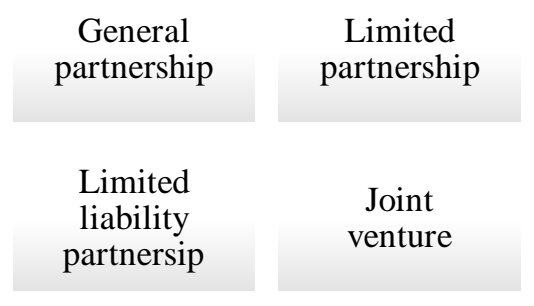

Source: Own editing

Figure 1. Types of business partnership

Most business partnerships are general partnerships. In the general partnership, all partners have responsibility for the business. For business debts the partners' unlimited liability. General partners share the benefits and obligations of the business. This means that a general partner can be held personally liable for the partnership's debts (Dugger, 2013).

There are other types of business partnerships as such as a limited partnership. In the limited partnership at least one owner is not burdened with full personal liability for debts of the business. A limited partnership is a business partnership where at least one owner is a general partner, as well as at least one owner, is a limited partner. The partners make every day difficult business decisions. The partners are personally liable for business debts. The limited partners simply invest in the business. The limited partners have little control over business operations (Dugger, 2013).

The limited liability partnership is a corporate business vehicle that enables professional expertise and entrepreneurial initiative to combine and operate in a flexible, innovative and efficient manner, providing benefits of limited liability while allowing its members the flexibility for organizing their internal structure as a partnership (The Limited Liability Partnership Act of India, 2008).

The major problem we may encounter in defining joint venture is to distinguish as to whether a joint venture is really a business organization or just a contractual arrangement. In respect, people find different kinds of literature and legal instruments. People defining joint venture in different ways (Asfaw, 2010). Chiffres (1994) gives a detailed and comprehensive definition of the joint venture as following: Joint Venture is an association of persons with intent, by way of contract, express or implied, to engage in and carry out a single business venture for joint profit. Such persons combine their property, money, effects, skill and knowledge pursuant to an agreement. There shall be a community of interest among the parties as to the purpose of the understanding. Each joint ventures must stand in the relation of principal, as well as an agent as to each of the other covertures within the general scope of the enterprise.

\section{Advantages and disadvantages of business partnership}

A business partnership is one of the most common forms to run a business in the world.

The business partnership offers a lot of advantages to those who choose to use it. So advantages of a partnership are as follows (Korchak, 2017; https://www.informdirect.co.uk/businessmanagement/partnership-business-advantages-and-disadvantages/):

$>$ less formal with fewer legal obligations;

easy to get started;

$>$ sharing the burden;

access to knowledge, skills, experience and contacts;

better decision-making;

privacy;

ownership and control are combined;

more partners, more capital; 
prospective partners;

easy access to profits.

While there are lots of benefits of a partnership business, this model also carries a number of important disadvantages. So the disadvantages of partnerships are as follows:

the business has no independent legal status;

unlimited liability;

perceived lack of prestige;

limited access to capital;

potential for differences and conflict;

slower, more difficult decision making;

profits must be shared;

personally demanding;

taxation;

limits on business development.

Lots of the other disadvantages people have looked at the combine to restrain the growth of most partnerships. For any business looking to achieve massive growth, a combination of unlimited liability, a lack of commercial status and lack of funding opportunities in the eyes of the world is hardly the perfect recipe for success. Options for the partners eventually to exit the business and profit from it can be complicated. Particularly if it's possible for the departure of one partner at an earlier date from a business partnership.

Benefits of the business partnership (Profit Blog, 2019) are:

Access to knowledge. Firms need a wealth of knowledge. That knowledge comes in bounty with business partnership agreements. This gives a partner the opportunity to grow and learn from another's perspective. All of the knowledge would be put into use to further build brand and business in the future.

Competitive advantage. Partnerships increase lease of knowledge, expertise and resources available to make better products and reach a greater audience.

$>$ It enhances the business' credibility and image. The right business partnership will enhance the ethos of the firm. When the firm that shares the same goals and vision join forces, strength and the influence of each organization can grow dramatically. The stronger business provides better products and delivers more qualitative services to customers. This boosts overall brand equity.

$>$ It increases the customer base. Through a functional business partnership agreement, the business would grow its customer base. It could be through a direct agreement have with a firm who offers products that are complementary to own. This alone would help in growing the customer base as customers are drawn to great products and services.

Long term stability. The goal of businesses is to reach its set corporate goals and remain relevant for a long time. Having business partners mean businesses are no longer operating in isolation. Partner will have access to more innovation, knowledge, expertise and funds. A great business partnership makes better, lifts up the weaknesses, and enhances the strengths.

If you have considered to help grow your business or to answer your current business needs, then the business partnership can be the best solution. Becoming aware of the advantages and disadvantages of a business partnership is crucial. This is the first step if you're thinking of venturing into a partnership. The following findings provide some useful insights into the advantages and disadvantages of a partnership (Martinuzzi, 2017).

A partnership may offer many benefits for your particular business:

bridging the gap in expertise and knowledge;

more cash;

cost savings; 
$>$ more business opportunities;

better work/life balance;

moral support;

new perspective;

potential tax benefits.

Let's take a look at some of the downsides of a partnership:

liabilities;

loss of autonomy;

emotional issues;

future selling complications;

lack of stability.

In analyzing some of the advantages and disadvantages of a partnership, you may conclude that the advantages outweigh the disadvantages. Some of the disadvantages of a partnership may be overcome with due diligence, proper investigation and a detailed, written, business agreement. Carefully evaluate all the advantages and disadvantages of a partnership in relation to your financial situation and mindset. A business partnership is a long-term commitment. It is based on finding the right person, someone you trust and enjoy being together with the work.

\section{Principles of the business partnership, success factors and reasons for failure}

Figure 2 shows the principles of business partnership and factors of a successful business partnership.

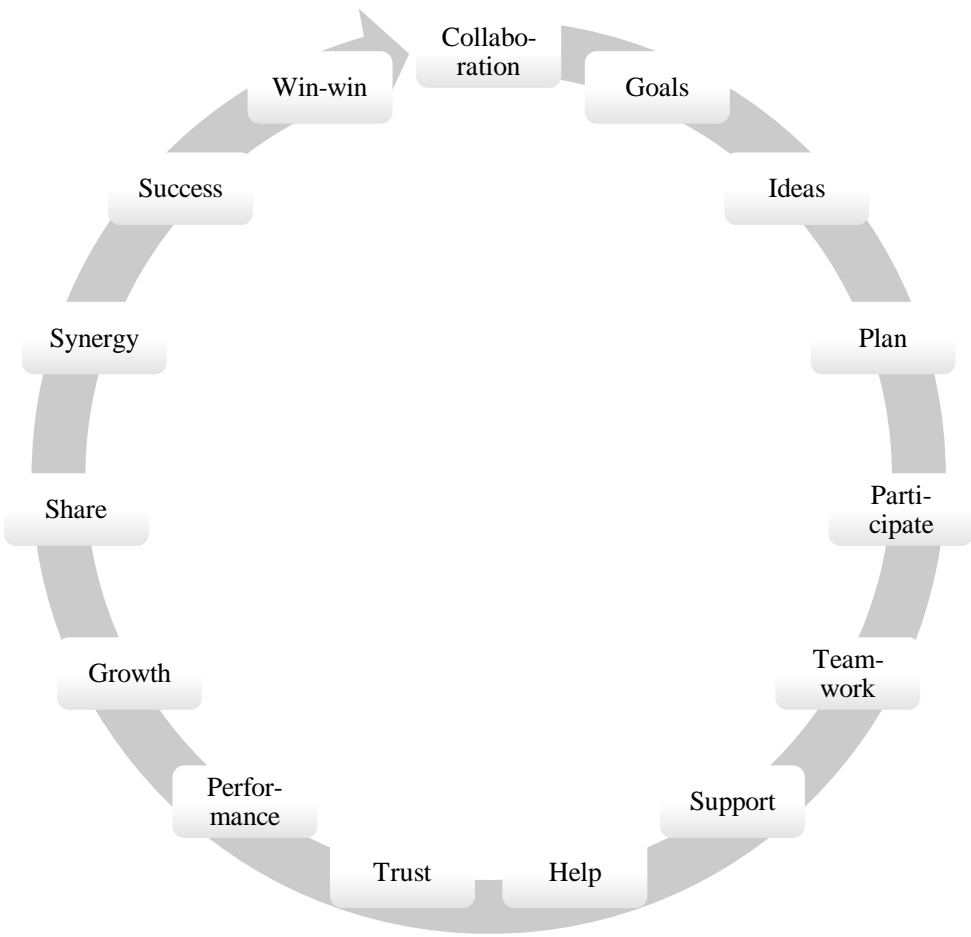

Source: Own editing

Figure 2. Principles of business partnership and success factors

It is great to form partnerships with other businesses. However, what any smart business owner must consider before signing on the dotted lines of a partnership agreement is that not all partnership agreements work out as planned. Some firms have generated massive problems for themselves by working with poorly-aligned partners that fail to bring anything to the table. You shouldn't make the same mistake. To avoid potential pitfalls, consider the following 3 factors (Figure 3). 
Source: Own editing

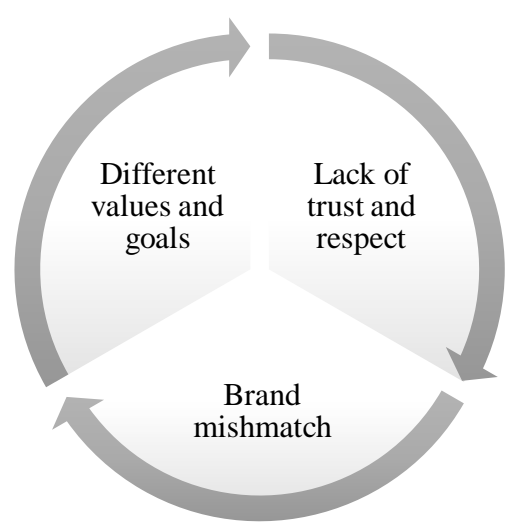

Figure 3. Reasons for failure

To avoid potential pitfalls, consider the following 3 factors (Profit Blog, 2019):

Trust and respect. When starting a business, the secret to the success of every partnership agreement is rooted in trust and respect between the partners. You must be able to trust the decision making, vision, competence and temperament of your partner and vice versa. Make sure to respect one another's personalities and abilities.

Brand alignment. Before starting a partnership, know exactly what each business does. Know exactly how your brands align. Form an alliance which has a way of setting goals and simultaneously propagating the objectives of each business.

Similar values and shared goals. It is important to form a partnership agreement with a firm whose corporate values and goals and augment your own. There are firms whose main focus is to make a profit and maximize shareholders wealth. Others are more concerned about corporate social responsibility. These firms put profit-making as a secondary objective. Partnering with a business that doesn't share primary objectives may lead to a clash of values and risk driving a wedge between the firms. This will likely lead to the death of the agreement.

\section{Methodology and Research Methods}

The main goal of this study is to examine the role and the importance of business partnership in Google Trends from 2004 to the present worldwide by country in the fields of science, business. The search and query time was 14.01.2020. Another goal of the study is to look at how often the term business partnership appears in Google books, with the help of Google Books Ngram Viewer, over a period of time between 1950 and 2008, as well as in database of Science Direct, with the help of Science Direct's search function, over a period of time between 1950 and 2019.

Google Trends (Figure 4) is a search trends feature. The Google Trends shows over a given period of time how frequently a given search term is entered into Google's search engine. It relatives to the site's total search volume. Google Trends can be used to discover event-triggered spikes in keyword search volume in addition to comparative keyword research. Google Trends provides keyword-related data. It gives about the keyword researcher is looking for geographical information and search volume index about search engine users.

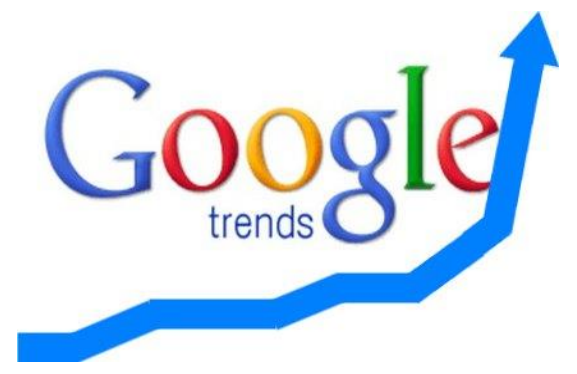

Source: Google Trends

Figure 4. Google Trends icon 
Google Trends shows related search terms also. The program shows that too how search interest varies by country. The researcher can also enter a search term into the search box to see how search volume has varied for that both over time and in different geographical locations. People can change the category, the geographical location, the time frame (from 2004) or industry, and type of search (web, news, shopping, or YouTube) for more accurate and detailed (https://www.wordstream.com/google-trends).

For the text of Google, the Google Books Ngram Viewer (Figure 5) is an online search platform. With the help of the program, searches can be conducted for the years between 1800 and 2009 in the text of Google in different languages. When entering phrases into the Google Books Ngram Viewer, it displays a graph showing how those phrases have occurred in a corpus of books over the selected years (https://books.google.com/ngrams/info).

\section{Google Books Ngram Viewer}

Source: https://books.google.com/ngrams

Figure 5. Google Books Ngram Viewer icon

Science Direct is a full-text database. Science Direct has publisher Elsevier. The Science Direct provides a combination of the services provides the best and broadest access to multiple types of electronic sources. Available content of Elsevier Science Direct in Hungary: more than 2500 full-text, reviewed journals, 39000 e-books, 17000 links to multiple journals covering all areas of scientific life, more than 16 million full-text articles (https://www.elsevier.com/solutions/sciencedirect).

\section{Results}

In the following, the research summarizes the frequency of the investigated term that is a business partnership in Google searches with the help of Google Trends. After that, the research summarizes the frequency of the phrase of the business partnership in Google Books with the help of Google Books Ngram Viewer, finally in the database of Science Direct, with the help of Science Direct's search function.

\section{Business partnership in Google Trends}

Table 1 summarizes the worldwide interest frequency of the investigated term in Google Trends. The numbers represent the search interest relative to the highest point in the graph for the country and city and time period. A value of 100 is the highest popularity of the term; a value of 50 indicates that the term is half as popular. 0 means that there is not enough data for the expression (Kiss, 2019).

Table 1 . A top year and bottom year of interest and interest by country and city

\begin{tabular}{|c|l|l|l|l|}
\hline Interest/Category & Bottom year & \multicolumn{1}{|c|}{ Top year } & \multicolumn{1}{c|}{ Top 5 country } & \multicolumn{1}{c|}{ Top 5 city } \\
\hline & & & 1. Botswana; & 1. Accra; \\
business & & & 2. Jamaica; & 2. Nairobi; \\
and & \multirow{2}{*}{$12.2006: 29$} & $07.2004: 100$ & 3. Zimbabwe; & 3. Manila; \\
industry & & & 4. Ghana; & 4uezon City; \\
& & & 5. Uganda. Cebu. \\
\hline
\end{tabular}

Source: Own editing based on Google Trends' data

Top year of the interest frequency of business partnership was 2004 worldwide in business and industry categories. Bottom year of interest frequency was 2006.

In the following, the research presents the search frequency over time for business partnership on average by business and industry category and by country in Google Trends.

Figure 6 shows the interest frequency of business partnership in Google Trends from 2004 to the present by business and industry category. 


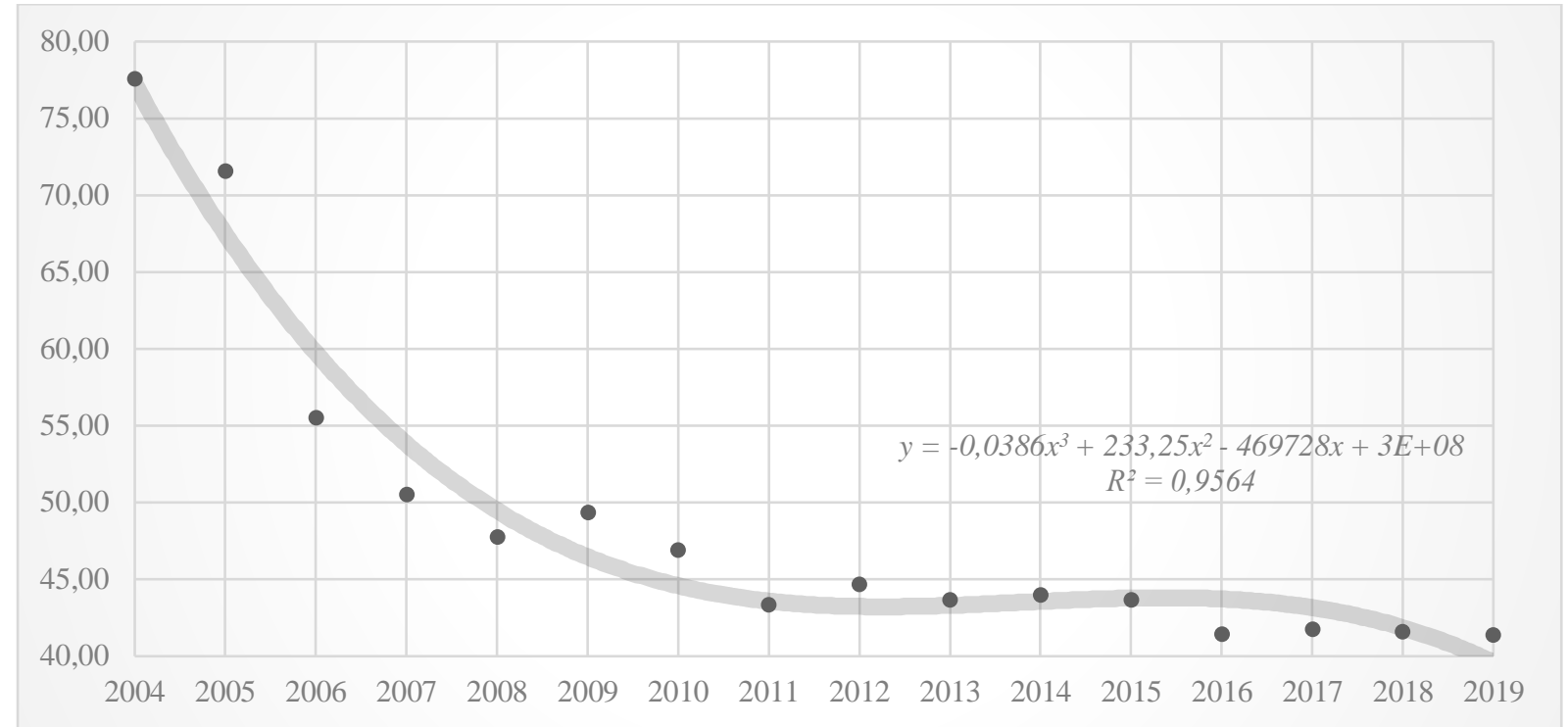

Figure 6. Interest over time on average

Source: Own editing based on Google Trends' data

Figure 6 shows the highest interest frequency of business partnership in the business and industry category. On average the highest interest frequency was in 2004 in the examined category. A third-degree polynomial downward trend can be fitted to the time series. In the case the value of $\mathrm{R}^{2}$ is good.

Figure 7 exhibits the interest frequency of business partnership in Google Trends by top country and city in the business and industry category. It shows where the term was most popular during the given time period. Google Trends shows during the given time period where the term was most popular. Values represented by various shades of blue and grey are on a scale of 0 to 100.100 (dark blue) is the place with the highest number of searches relative to the total number of searches. A value of 50 (light blue) indicates where the popularity is half. 0 (light grey) indicates where there is not enough data for the expression. Note: A higher value represents a higher proportion of all queries than a higher absolute number of queries. For example, a tiny country where $60 \%$ of queries related to the business partnership will score twice as big as a huge country where only $30 \%$ of queries apply to business partnership (Kiss, 2019).

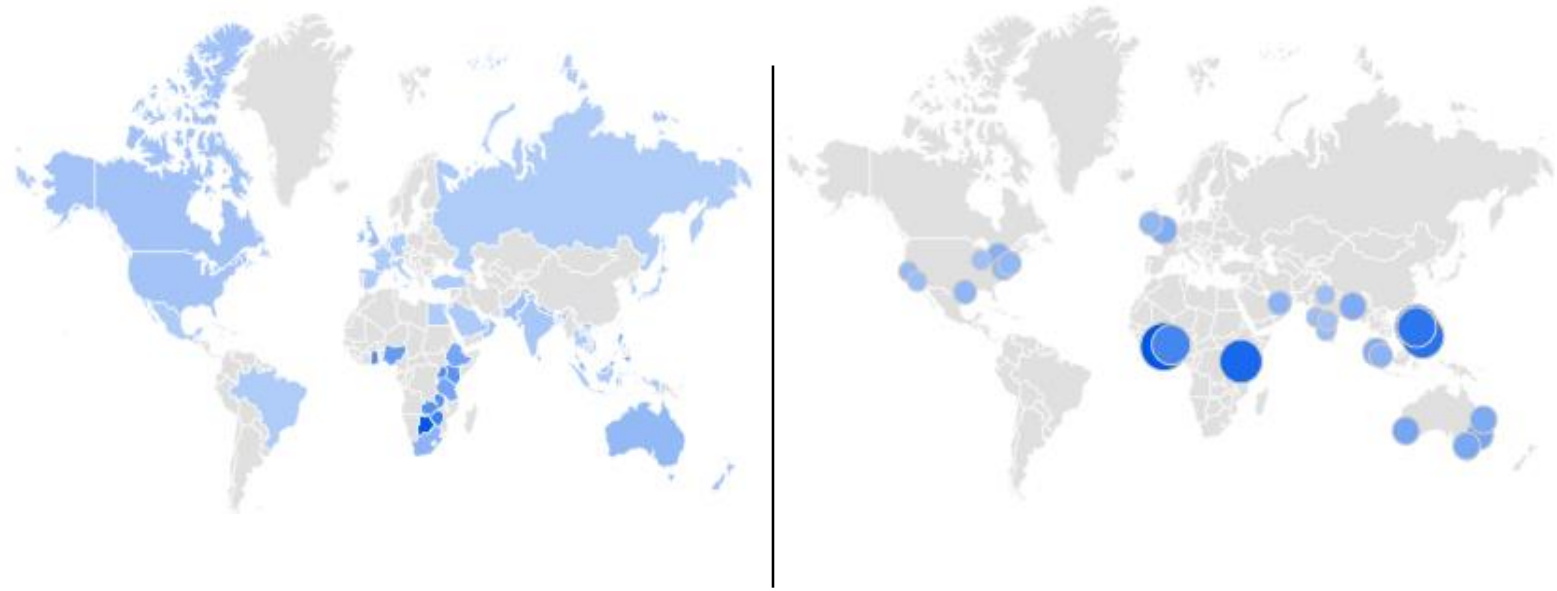

Figure 7. Interest by country and city in the business and industry category

Source: Google Trends

The map depicted in Figure 7 shows that most people searched in Botswana (100), in Jamaica (72), in Zimbabwe (64), in Ghana (56) and in Uganda (55) for the term business partnership. Interestingly, these countries are all located on the African continent, except Jamaica. What could be the reason that this term is so popular there? In Eastern and Southern Africa, there is a scanty piece of information regarding the business activities of private individuals. The official records according to in the region there is still a limited business activity undertaken by private individuals. The changes in the late 1980s necessitated the private individuals, the national states and the institutions to seek for a closer co-operation in business and other activities. Ethical issues have been on top of the agenda of every nation in Eastern and Southern Africa. This was important, because of the perceived development and improvement of business enterprises. Each national government in 
the region tries to accept such a challenge. The nations designed measures to enhance regional and national ethics compatibility in business. Many institutions and various stakeholders in Eastern and Southern Africa are encouraged to participate and co-operate for the betterment of the region (Milanzi, 1997; Kiss, 2019).

What could be the reason this term is so popular also in Jamaica? In certain commercial areas in the country, Jamaican businesses operating are faced with a dilemma. This derives from the unique characteristics of their economic and social space. They are faced with the challenge of maintaining profitability and functioning as responsible corporate citizens while coping with the extortion carried out by members of the informal militias of garrison communities acting on behalf of the dons who run these communities (Charles, 2007; Kiss, 2019).

Another map depicted shows that most people searched in Accra (100), in Nairobi (86), in Manila (85), in Quezon City (84) and in Cebu (77) for the term business partnership. Accra is the capital of Ghana, Nairobi is the capital of Kenya. Ghana is in West Africa, Kenya is in east Africa. Manila is the capital of the Philippines, Quezon City is the most populated city in the Philippines and Cebu is a city in the Philippine Islands. The Philippines is a country represented by one of the most beautiful islands in the world which is attractive not only to tourists but also to the investors interested in doing business there. Providing incentives, and having business-friendly legislation towards foreign investment, the Philippines government allows for the establishment of companies here under very advantageous conditions. A partnership company is a legal form of business operation in the Philippines between two or more individuals who share and manage both the profits and losses of the company. After corporation, a partnership company in one of the most preferred business entities in the Philippines.

In the following, the research presents the search frequency over time for types of business partnership on average by business and industry category and by country in Google Trends.

Figure 8 shows the interest frequency of types of the business partnership (general partnership with blue, limited partnership with red, limited liability partnership with a yellow and joint venture with green) in Google Trends from 2004 to the present by business and industry category.

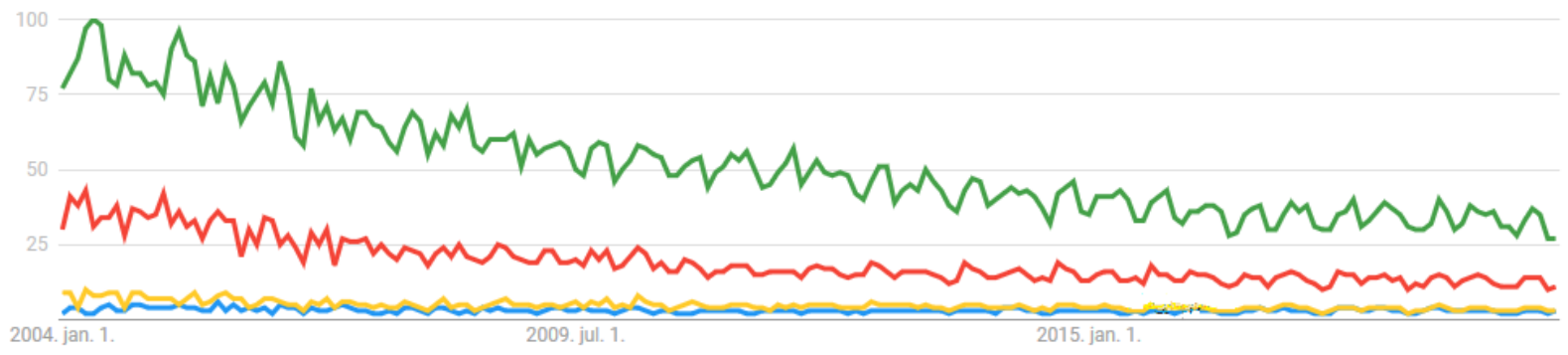

Source: Google Trends

Figure 8. Interest over time on average

Figure 8 shows the highest interest frequency of types of business partnership in the business and industry category in 2004. Most people inquired about the joint venture and limited partnership.

Figure 9 exhibits the interest frequency of types of business partnership in Google Trends by top country and city in the business and industry category.
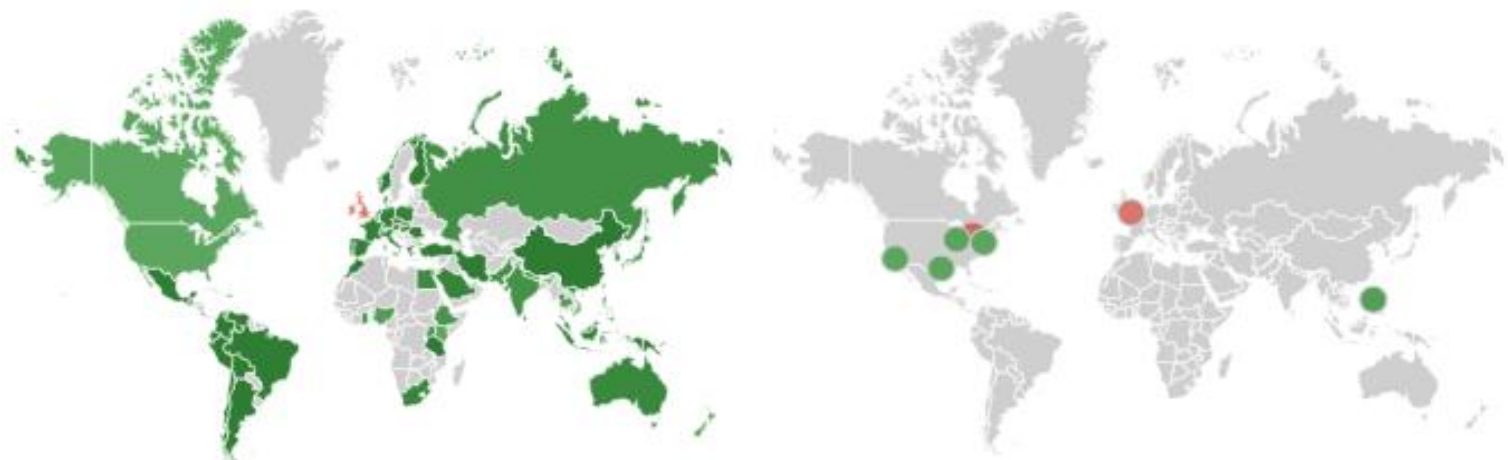

Figure 9. Interest by country and city in the business and industry category

Source: Google Trends

The map depicted in Figure 9 shows that most people searched in the Philippines, in Ethiopia, in the USA, in Canada and in Kenya for the types of business partnership. 
Another map depicted shows that most people searched in Quezon City, in Los Angeles, in Chicago, in Houston and in New York for the types of business partnership.

\section{Business partnership in Google Books}

Figure 10 shows the frequency of appearance of business partnership in the Google Books' database in chronological order between 1950 and 2008. The use of term business partnership shows a third-degree polynomial growing trend, represented by a value of 0.9833 for $R^{2}$.

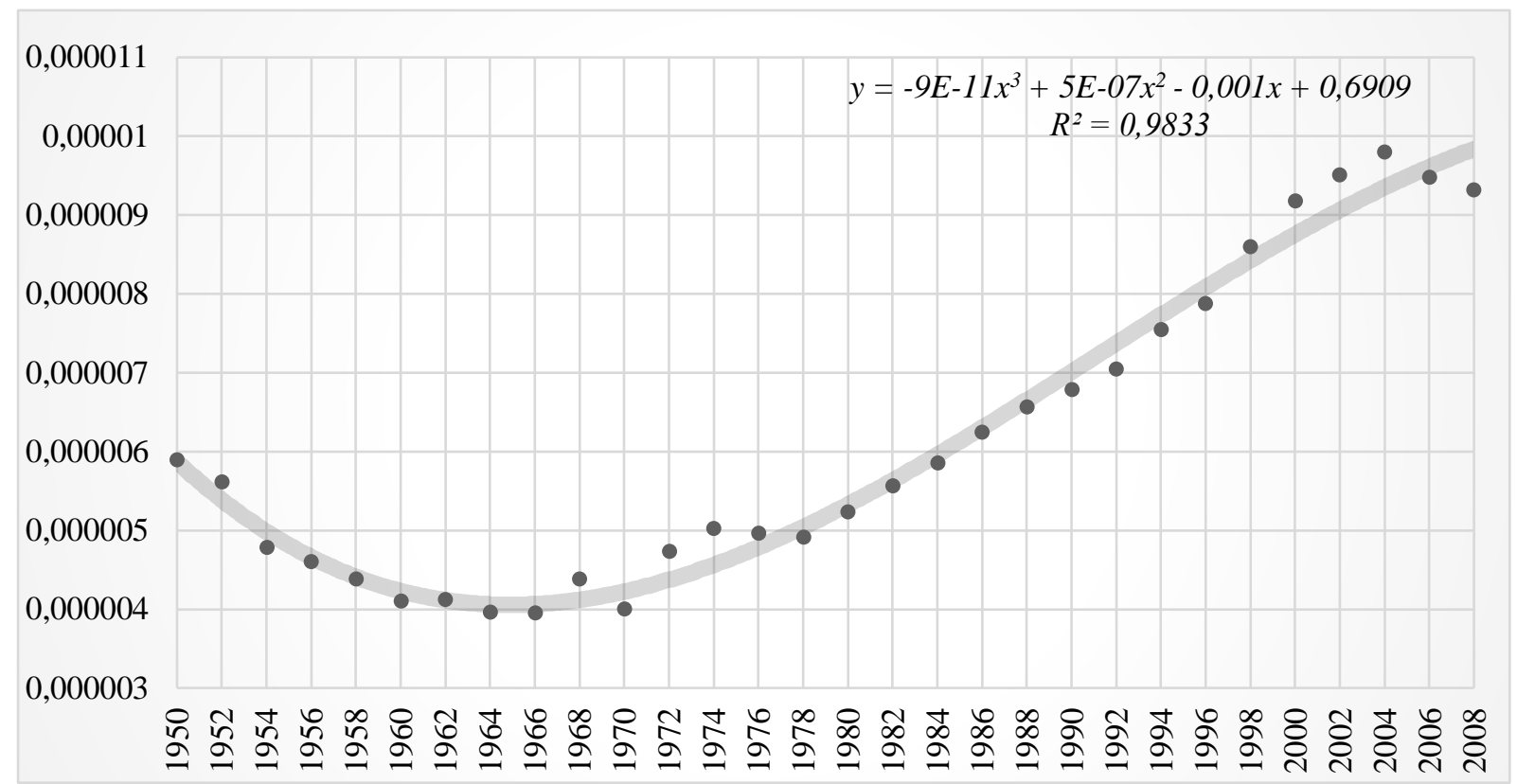

Figure 10. Frequency of appearance of business partnership in the Google Books` database Source: Own editing based on Google Books Ngram Viewer's data

From 1950 to 1970 the frequency of appearance of business partnership in the Google Books` database has been decreasing continuously. From 1972 the frequency has been growing gradually, then from 2006, the frequency has been decreasing gradually.

\section{Business partnership in Science Direct}

In the following, the research summarizes the frequency of business partnership in Science Direct's database with the help of Science Direct's search function.

Figure 11 shows the frequency of appearance of business partnership in the Science Direct's database in chronological order between 1956 and 2019.

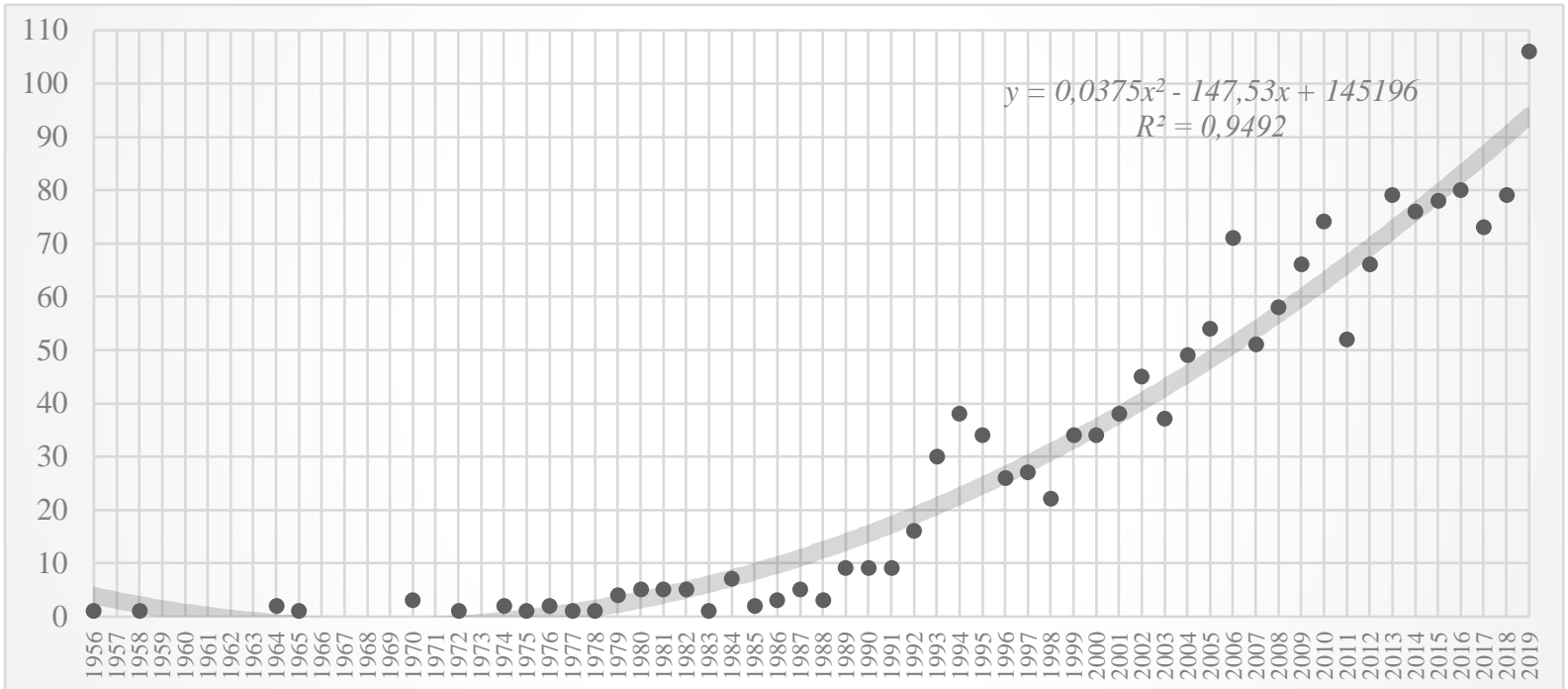

Figure 11. Frequency of appearance of business partnership in the Science Direct's database

Source: Own editing based on Science Direct's data

The use of term business partnership shows a second-degree polynomial growing trend, represented by a value of 0.9492 for $\mathrm{R}^{2}$. 


\section{Conclusions and Discussions}

The partnership is a relationship in which two or more people, organizations or countries work together as partners. This is a formal agreement between parties to achieve a well-defined goal. There are many forms or types of partnership, one of which is a business partnership.

A business partnership is a person-to-person relation, an association of two or more persons that carries out joint business activities and distributes profits between them.

The main goal of this study was to examine the role and the importance of business partnership in Google Trends from 2004 to the present worldwide by country in the fields of science, business. Another goal of the study was to look at how often the term business partnership appears in Google books, with the help of Google Books Ngram Viewer, over a period of time between 1950 and 2008, as well as in database of Science Direct, with the help of Science Direct's search function, over a period of time between 1950 and 2019.

Top year of the interest frequency of business partnership was 2004 in the Google Trends worldwide in business and industry categories. Bottom year of interest frequency was 2006. On average the highest interest frequency was in 2004 in the examined category. A third-degree polynomial downward trend can be fitted to the time series. In the case the value of $\mathrm{R}^{2}$ is good. The map shows that most people searched in Botswana (100), in Jamaica (72), in Zimbabwe (64), in Ghana (56) and in Uganda (55) for the term business partnership. Interestingly, these countries are all located on the African continent, except Jamaica. Another map shows that most people searched in Accra (100), in Nairobi (86), in Manila (85), in Quezon City (84) and in Cebu (77) for the term business partnership.

Types of business partnership show the highest interest frequency in the business and industry category in 2004 in the Google Trends. Most people inquired about the joint venture and limited partnership. The map shows that most people searched in the Philippines, in Ethiopia, in the USA, in Canada and in Kenya for the types of business partnership. Another map shows that most people searched in Quezon City, in Los Angeles, in Chicago, in Houston and in New York for the types of business partnership.

The use of term business partnership shows in the Google Books a third-degree polynomial growing trend, represented by a value of 0.9833 for $\mathrm{R}^{2}$. From 1950 to 1970 the frequency of appearance of business partnership in the Google Books` database has been decreasing continuously. From 1972 the frequency has been growing gradually, then from 2006, the frequency has been decreasing gradually.

The use of term business partnership shows in the Science Direct a second-degree polynomial growing trend, represented by a value of 0.9492 for $\mathrm{R}^{2}$.

Summarizing all these results, we can conclude that while people in developing countries in Africa and in Jamaica were most sought after for expressing business partnerships, people in developed countries were more interested in types of business partnerships. While the number of terms searched on Google has decreased, the number of terms in the scientific database in Science Direct has increased.

The Philippines is attractive to investors. The government provides incentives and enacts entrepreneur-friendly legislation. The government provides favorable conditions for starting a business. In the Philippines, the partnership company is one of the most advantageous forms of business enterprise.

In Eastern and Southern Africa, individuals may have had limited business activities in the past. By the end of the 1980s, the pursuit of co-operation came to the forefront of the business. Business development has become important for nations. Individual nations have developed action plans. These nations strove for ethical compatibility in business. They were encouraged to participate and work together to develop the area.

In Jamaica, people are facing a dilemma because of the unique characteristics of its economic and social space. People are challenged to act and act as a responsible corporate citizen. In the meantime, they must deal with the extortion of garrisons of garrison communities who act on behalf of the dons.

\section{References}

1. Asfaw, S. (2010). The Exploration of the Legal Framework and the Practice Relating to "Joint Ventures" in Ethiopia: a Comparative Approach. Law \& Practice of Ethiopian "Joint Ventures": Comparative Study. Addis Ababa University, School of Law, Graduate School. Available at: https://chilot.me/wpcontent/uploads/2013/01/the-exploration-of-the-legal-framework-and-the-practice-relating-toe2809cjoint-venturese2809d-in.pdf. 
2. Bagdonas, E, Kazlauskienè, E. (2000). Biznio ịvadas. Kaunas [Introduction to Business. Kaunas]: KTU University Publishing House. Business introduction, in Lithuanian. Available at: http://bazekon.icm.edu.pl/bazekon/element/bwmeta1.element.ekon-element-000171356253.

3. Barlow, J., Jashapara, A. (1998). Organizational Learning \& Inter-Firm Partnering in the UK Construction Industry. The Learning Organization, 5(2), 86-98. Available at: https://www.researchgate.net/publication/235255446_Organisational_Learning_and_Inter-

Firm_Partnering_in_the_UK_Construction_Industry.

4. Charles, C. (2007). Business Ethics in Jamaica and the Problem of Extortion by Counter Societies. Ethical Perspectives for Caribbean Business. Eds. Cowell, N. E., Campbell, A., Chen, G. \& Moore, S., Arawak Publications, 2007. Available at: https://ssrn.com/abstract=2372120 Accessed 11 August 2019.

5. Draft, R.L. (2000). Management. Philadelphia: Drysden Press. Available at: https://trove.nla.gov.au/work/5967170?q\&versionId=211018308.

6. Dugger, A. (2013). What Is a Limited Partnership? - Definition, Advantages \& Disadvantages. Chapter 22/Lesson 6. Available at: https://study.com/academy/lesson/what-is-a-limited-partnership-definitionadvantages-disadvantages.html\#transcriptHeader Accessed 22 January 2020.

7. FinacePal by CommunityTax (2019). Types of Business Partnerships: Breaking Down the Options. Available at: https://www.financepal.com/types-of-business-partnerships/ Accessed 30 January 2020.

8. Harnesk, R. (2004). Partnership with internal customers - a way to achieve increased commitment. The TQM Magazine, 16(1), 26-32. https://doi.org/10.1108/09544780410511452.

9. Kiss, L.B. (2019). Examination of the Role of Business Ethics with Google Trends. Business Ethics and Leadership, 3(3), 25-38. http://doi.org/10.21272/bel.3(3).25-38.2019.

10.Korchak, J. (2017). Advantages and Disadvantages of a Partnership Business. Available at: https://www.informdirect.co.uk/business-management/partnership-business-advantages-anddisadvantages/ Accessed 16 January 2020.

11.Martinuzzi, B. (2017). What Are the Advantages and Disadvantages of a Partnership? Available at: https://www.americanexpress.com/en-us/business/trends-and-insights/articles/what-are-the-advantagesand-disadvantages-of-a-partnership/ Accessed 20 January 2020.

12.Milanzi, M.C. (1997). Business Ethics in Eastern and Southern Africa. Journal of Business Ethics, 16(14), 1549-1553. https://doi.org/10.1023/A:1005811014294.

13.Nakrošis, V. (2007). Partnerystès modeliai ES valstybès narèse [The models of partnership in members of ES]. Available at: http://www.nrda.lt/Partnership.pdf Accessed 21 January 2020.

14.National Conference of Commissioners on Uniform State Laws (1994). Revised Uniform Partnership Act. $\S 101$. Available at: https://users.wfu.edu/palmitar/ICBCorporations-Companion/Conexus/UniformActs/RUPA1997.pdf Accessed 21 January 2020.

15.Parliament of India (1932). The Indian Partnership Act. 1932 Section 4 of the Indian Partnership Act. Available at: https://www.mca.gov.in/Ministry/actsbills/pdf/Partnership_Act_1932.pdf Accessed 21 January 2020.

16.Parliament of India (2008). The Limited Liability Partnership Act. No. 6 of 2009. Available at: http://www.mca.gov.in/Ministry/actsbills/pdf/LLP_Act_2008_15jan2009.pdf Accessed 22 January 2020.

17.Profit Blog (2019). The Importance of Partnership in Business. Available at: https://www.profit.co/blog/thealphabet-p/partnership/the-importance-of-partnership-in-business/ Accessed 20 January 2020.

18. The Commissioner of Law Revision, Malaysia (1961). Laws of Malaysia Act 135 Partnership Act. Sec 3(1) of the Partnership Act. Available at: http://www.commonlii.org/my/legis/consol_act/pa19611974229/ Accessed 21 January 2020.

19.WordStream (2017). Google Trends: What Is Google Trends? Available at: https://www.wordstream.com/google-trends Accessed 10 August 2019. 